\title{
Pengaruh Dental Health Education Cara Menyikat Gigi disertai Demonstrasi terhadap Tingkat Pengetahuan Kebersihan Gigi pada Siswa Kelas V SDN Padangdangan 1
}

(The Effect of Dental Health Education on How to Brush Teeth with Demonstration on the Knowledge Level of Dental Hygiene in Grade 5 Students of SDN Padangdangan 1)

\section{Zakiyah Yasin}

Fakultas IImu Kesehatan Universitas Wiraraja Madura

\begin{abstract}
Abstrak
Penyakit gigi dan mulut masih menjadi masalah kesehatan di Indonesia. Penyakit gigi dan mulut sangat mempengaruhi derajat kesehatan, proses tumbuh kembang bahkan masa depan anak. Data tentang penyakit gigi pada anak Indonesia, menunjukkan bahwa kondisi tersebut sudah pada tahap khawatir. Diperlukan penelitian pendidikan kesehatan yang efektif tentang kebersihan gigi pada anak balita. Penelitian ini bertujuan untuk mengetahui pengaruh DHE terhadap pengetahuan kebersihan gigi pada siswa kelas $\vee$ SDN Padangdangan 1. Metode penelitian ini adalah quasi eksperimen, menggunakan desain Pretest-Postest Control. Penelitian ini dilaksanakan di SDN Padandangan 1 dengan jumlah populasi adalah seluruh siswa kelas $V$ SDN Padandangan 1. Teknik pengambilan sampel dalam penelitian ini adalah total sampling dengan jumlah responden 32 yang dibagi menjadi dua kelompok yaitu kelompok kontrol dan kelompok pelaksana. Pengumpulan data dilakukan dengan menggunakan kuesioner. Hasil penelitian ini menunjukkan bahwa sebelum DHE diterapkan pada kelompok pelaksana, siswa memiliki pengetahuan yang kurang, yaitu 9 siswa $(56,2 \%)$ dan setelah DHE diterapkan, nilai pengetahuan siswa meningkat, yaitu 16 siswa $(50,0 \%)$. ). Hasil Uji Willcoxon Sign Rank Test $P=0,005(p<\alpha)$, pemberian DHE melalui demonstrasi dental rush yang baik dan benar kepada siswa kelas $V$ dapat meningkatkan nilai pengetahuan siswa. Edukasi kesehatan gigi adalah cara menyikat gigi yang benar dengan menggunakan alat bantu yang menarik, seperti manekin phantom yang dapat menarik perhatian pendidik. Teknik praktik langsung juga melibatkan banyak indera sehingga materi dari pendidik lebih menyentuh memori jangka panjang.
\end{abstract}

Kata kunci : DHE, menggosok gigi, pengetahuan.

\begin{abstract}
Dental and oral disease are still become health problem in Indonesia. Dental and oral diseases greatly affect the degree of health, growth process and even the future of children. Data about dental diseases on Indonesian children, indicates that condition is already at worried stage. Research of effective health education about dental hygiene to toddler children needed. This study aim is to determine the influence of DHE against knowledge of dental hygiene on Grade $V$ students in SDN Padangdangan 1. The method of this study was quasi experiment, use PretestPostest Control design. This study was conducted in SDN Padandangan 1 with total population was all of Grade $V$ students in SDN Padandangan 1. The sampling technique in this study was total sampling with number of respondents was 32 divided by two groups, there were control group and implementation group. The data collected by using questionnaires. The result of this study shows that before DHE applicated to implementation group, students have less knowledge, that was 9 students $(56,2 \%)$ and after DHE applicated, value of students' knowledge was increase, that was 16 students $(50,0 \%)$. The result of Willcoxon Sign Rank Test detired $P=0,005(p<a)$, administering DHE through good and correct teeth rushing demonstration to Grade $V$ students can increase the value of students' knowledge. Dental health education is the right way to brush your teeth by using an interesting tool, such as phantom mannequin that can make attention from educator. Direct practice echnique is also involves many senses so the material from educator was more touches long erm memory.
\end{abstract}

Keywords : DHE knowledge, teethbrushing

Korespondensi (Correspondence) : Zakiyah Yasin. Fakultas IImu Kesehatan Universitas Wiraraja. Jl. Raya SumenepPamekasan KM. 05 Patean, Sumenep, 69451, Email: zakiyahfik@wiraraja.ac.id

Penyakit gigi dan mulut masih menjadi masalah kesehatan di Indonesia. Penyakit gigi dan mulut sangat mempengaruhi derajat kesehatan, proses tumbuh kembang, bahkan masa depan anak. Anak-anak menjadi rawan kekurangan gizi karena rasa sakit pada gigi dan mulut menurunkan selera makan mereka.Kemampuan belajar anak pun akan menurun sehingga akan berpengaruh pada prestasi belajar. ${ }^{1}$

Data-data mengenai penyakit gigi yang dialami anak-anak dan usia dewasa di Indonesia menunjukkan kondisi yang sudah dalam tahap mengkhawatirkan. Hal ini memperlihatkan masih rendahnya kesadaran akan pentingnya merawat kesehatan gigi dan mulut, yang sebenarnya sangat esensial bagi kesehatan secara umum dan juga kualitas hidup seseorang. Masih rendahnya pengetahuan terhadap cara menggosok gigi yang benar pada masyarakat dikarenakan kurangnya sosialisasi terhadap masyarakat di pedesaan oleh pemerintah daerah, hal ini ditujukkan masih tingginya angka karies dan penyakit gigi lainnya.

Menurut Riskesdas tahun 2013 terdapat 93 juta lebih penduduk Indonesia menderita karies aktif. Sebagian besar anak-anak Indonesia belum menyikat gigi dengan cara yang tepat dan pada waktu yang benar. Akibatnya, 60 persen anak menderita karies gigi. Data tersebut diperoleh dari Rumah Sakit 
Gigi dan Mulut (RSGM) Fakultas Kedokteran Gigi (FKG) Universitas Moestop, sebanyak 60 persen anak yang datang berkunjung mengalami keluhan pada karies gigi.

Di Jawa Timur dari sekitar 9 juta penduduk anak (usia di bawah 15 tahun) menderita karies, 462.232 anak memerlukan perawatan gigi dan mulut dan baru 305.400 anak yang menerima perawatan kesehatan gigi dan mulut. Data dinas kesehatan Kabupaten Sumenep anak menderita penyakit gigi di Kecamatan Pasongsongan pada tahun 2016 sebanyak 59 anak. Anak usia sekolah memiliki kegemaran untuk makan makanan yang manis, sedangkan orang tua kurang mempedulikan kebiasaan untuk menyikat gigi, jika seorang anak tidak mau menggosok gigi maka sebagai orang tua sebaiknya dapat memaksa anaknya untuk menggosok gigi terutama saat menjelang tidur malam. Bila seorang anak tidak terbiasa menggosok gigi maka dari kebiasaan tersebut dapat menyebabkan anak yang mengalami karies, dan akan dibawa hingga dewasa. ${ }^{2}$

Upaya kesehatan gigi perlu ditinjau dari aspek lingkungan, pendidikan, kesadaran masyarakat dan penanganan kesehatan gigi termasuk pencegahan dan perawatan. Aspek tersebut saling berhubungan dan saling mempengaruhi baik cara pencegahan dan perawatan gigi masyarakat (upaya kesehatan gigi masyarakat) maupun penaggulangan keadaan kesehatan gigi masyarakat,untuk mendapatkan hasil sebaik-baiknya dalam upaya kesehatan gigi (pencegahan penyakit gigi), perlu diketahui masalah yang berkaitan dengan proses terjadinya kerusakan gigi (karies gigi) termasuk etiologi karies gigi, resiko yang menyebabkan timbulnya karies gigi. ${ }^{3}$

\section{METODE PENELITIAN}

Rancangan penelitian yang digunakan, yaitu quasy-experiment, pretest-posttest control group design. Rancangan ini berupaya untuk mengungkapkan hubungan sebabakibat dengan cara melibatkan kelompok kontrol di samping kelompok eksperimental. ${ }^{4}$

Tabel 1. Desain Penelitian Eksperimen PretestPosttest Control Group

\begin{tabular}{|c|c|c|c|}
\hline Subjek & Pra & Perlakuan & Pasca-tes \\
\hline $\mathrm{K}-\mathrm{A}$ & 0 & I & Ol-A \\
\hline \multirow[t]{2}{*}{ K-B } & 0 & - & Ol-B \\
\hline & Time 1 & Time 2 & Time 3 \\
\hline $\begin{array}{l}\text { K-A, Subj } \\
\text { pembelajarc } \\
\text { sebelum i } \\
\text { (perlakuan); } \\
\text { (perlakuan) }\end{array}$ & $\begin{array}{l}\text { k perl } \\
\text { h; K-B, } \\
\text { tervensi } \\
O 1(\mathrm{~A}+\mathrm{B})\end{array}$ & $\begin{array}{l}\text { diberika } \\
\text { k kontrol; } \\
\text { rlakuan); } \\
\text { servasi sesud }\end{array}$ & $\begin{array}{lr}x & \text { metode } \\
O, & \text { Observas } \\
\text { l, } & \text { Intervens } \\
\text { dah } & \text { intervens }\end{array}$ \\
\hline
\end{tabular}

Pada kedua kelompok diawali dengan pembagian koesioner sebelum diberikan perlakuan (pretest). Kelompok intervensi diberikan perlakuan sedangkan kelompok kontrol tidak diberi perlakuan. Kemudian setelah dilakukan perlakuan berupa edukasi, penyuluhan dilakuan pembagian kuesioner kembali untuk melihat peningkatan kemampuan siswa. Dalam penelitian ini, peneliti menggunakan desain penelitian eksperimen (quasi experiment), dimana pada rancangan ini berupanya untuk mengungkapkan hubungan sebab akibat dengan cara melibatkan kelompok kontrol di samping kelompok eksperimental.

Penelitian ini dilakukan pada bulan Mei 2017 di SDN Padangdangan 1 Desa Padangdangan 1 Kecamatan Pasongsongan Kabupaten Sumenep. Sampel dalam penelitian ini adalah siswa kelas 5 di SDN Padangdangan 1 Kecamatan Pasongsongan Kabupaten Sumenep sebanyak 32 siswa. Dalam penelitian tehnik pengambilan data yang digunakan adalah Total Sampling, dimana dalam pengambilan data ada pertimbangan tertentu. Kritera dalam penentuan yaitu

1. Kriteria Inklusi : siswa SDN Padangdangan 1.

2. Kriteria Eksklusi : Siswa yang tidak masuk sekolah.

\section{HASIL}

Berdasarkan hasil penelitian tentang pengaruh dental health education cara menyikat gigi disertai demonstrasi terhadap tingkat pengetahuan kebersihan gigi pada siswa kelas V SDN Padangdangan 1 bulan Mei 2017 didapatkan hasil yang dapat dilihat pada tabel 2. Berdasarkan tabel 2, distribusi Pengetahuan Kebersihan Gigi pada Siswa Kelas V Kelompok Perlakuan Sebelum Penyuluhan menunjukkan sebagian besar siswa mempunyai tingkat pengetahuan menyikat gigi kurang, yaitu sebanyak 9 orang $(56,2 \%)$ distribusi pengetahuan kebersihan gigi pada siswa Kelas $\mathrm{V}$ kelompok perlakuan sesudah penyuluhan menunjukkan setengahnya siswa mempunyai tingkat pengetahuan menyikat gigi baik, yaitu sebanyak 8 orang (50\%) pada kelompok kontrol menunjukkan bahwa sebagian besar siswa mempunyai tingkat pengetahuan menyikat gigi kurang, yaitu sebanyak 12 orang (75\%). Berdasarkan tabel 2 menunjukkan bahwa dari 16 siswa kelas $\vee$ pada kelompok kontrol siswa mempunyai nilai pengetahuan kurang dan hanya 1 siswa yang mempunyai nilai pengetahuan baik. Berdasarkan tabel 2 , menunjukkan sebelum dilakukan penyuluhan kepada siswa kelompok perlakuan pada kelas $\checkmark$, 'dari 16 jumlah siswa yang menjadi sampel penelitian diperoleh hasil 9 siswa dengan nilai pengetahuan kurang dan sebanyak 2 siswa dengan nilai baik. Kemudian setelah dilakukan 
Tabel 2. Perbedaan Pengetahuan Kebersihan Gigi Pretest dan Postest pada Siswa Kelas $V$ pada Kelompok Kontrol dan Perlakuan di SDN Padangdangan 1 Tahun 2017

\begin{tabular}{lcccccccc}
\hline \multirow{2}{*}{ Kelompok } & \multicolumn{4}{c}{ Pretest } & \multicolumn{5}{c}{ Postest } \\
\cline { 2 - 9 } & $\mathbf{B}$ & $\mathbf{C}$ & $\mathbf{K}$ & $\boldsymbol{\Sigma}$ & $\mathbf{B}$ & $\mathbf{C}$ & $\mathbf{K}$ & $\Sigma$ \\
\hline Perlakuan & 2 & 5 & 9 & 16 & 8 & 7 & 1 & 16 \\
$(\%)$ & 12,5 & 31,3 & 56,2 & 100 & 50 & 43,8 & 62,2 & 100 \\
Kontrol & 1 & 3 & 12 & 16 & 1 & 3 & 12 & 16 \\
$(\%)$ & 6,2 & 18,8 & 75 & 100 & 6,2 & 18,8 & 75 & 100 \\
\hline \multicolumn{3}{c}{} & Total & & $\mathbf{3 2}$ & & Total & $\mathbf{3 2}$ \\
\hline
\end{tabular}

penyuluhan kepada siswa kelompok perlakuan pada kelas $V$ dari 16 jumlah siswa yang menjadi sampel penelitian diperoleh hasil 8 siswa dengan nilai pengetahuan menyikat gigi baik dan sebanyak 1 orang jumlah siswa dengan nilai pengetahuan buruk. Hal ini menunjukkan bahwa ada pengaruh dari pemberian penyuluhan pada siswa kelompok perlakuan. Hasil tabel diatas menunjukkan bahwa kegiatan penyuluhan melalui demonstrasi sikat gigi yang baik dan benar kepada siswa kelas $V$ dapat meningkatkan pengetahuan. Dari hasil analisa dengan menggunakan uji Wilcoxon diperoleh nilai $p=$ $0,005(P<\alpha)$. Dengan demikian dapat disimpulkan bahwa $\mathrm{Hl}$ diterima yang berarti dental health education cara menyikat gigi disertai demonstrasi dapat meningkatkat pengetahuan kebersihan gigi pada siswa kelas $\checkmark$ SDN Padangdangan 1.

\section{PEMBAHASAN}

Pengetahuan kebersihan gigi pada siswa kelas V SDN Padangdangan 1 pada kelompok perlakuan menunjukkan sebagian besar siswa mempunyai tingkat pengetahuan kurang yaitu sebanyak 9 orang, hal ini menunjukkan 3 poin kuesioner yang paling banyak salah yaitu cara menyikat gigi bagian samping, depan dan permukaan gigi. Keterampilan dalam menjaga kebersihan gigi mulut responden kurang memenuhi standar yang diharapkan karena para siwa belum pernah mendapatkan pendidikan kesehatan menggosok gigi sebelumnya..$^{6.7}$

Pendidikan kesehatan merupakan pendidikan yang tidak lepas dari proses belajar karena proses belajar itu ada dalam rangka mencapai tujuan pendidikan. Sebelum terjadi perubahan perilaku, seseorang akan mempunyai persepsi terhadap apa yang akan dijalaninya sehingga menimbulkan persepsi yang berhubungan dengan tingkat pengetahuan yang diperoleh dari informasi, sehingga bila informasi yang diterima kurang jelas, hasil pembelajaran yang didapat juga tidak optimal. Informasi yang diperoleh oleh responden mempengaruhi pengetahuan responden yang semula kurang akan berubah dengan sendirinya menjadi baik. Pengetahuan seseorang terhadap obyek mempunyai intensitas atau tingkat yang berbeda-beda. Proses pembelajaran yang tidak optimal akan mempengaruhi persepsi seseorang sehingga perubahan untuk berperilaku hidup sehat akan sulit didapatkan. Persepsi proses informasi juga berhubungan dengan seleksi perhatian, kode, dan ingatan. ${ }^{5}$

Pengetahuan kebersihan gigi pada siwa kelas V SDN Padangdangan 1 pada kelompok perlakuan menunjukkan sebagian besar siswa mempunyai tingkat pengetahuan baik yaitu sebanyak 8 siswa. sebelum diberi DHE yang 3 poin kuesioner banyak yang salah menjadi benar. Penyuluhan kesehatan gigi dan mulut (Dental Health Education) adalah pendidikan yang terancana dan terarah pada seseorang atau suatu kelompok masyarakat dengan memberikan motivasi untuk menanggulangi masalah kesehatan gigi dan mulut yang harus di laksanakan oieh pusat kesehatan masyarakat (puskesmas) secara terpadu agar tercapainya tujuan program pembangunan nasional yang membantu menghasilkan penghargaan masyarakat akan kesehatan gigi dan mulut, Terutama mau merubah perilaku kearah yang lebih baik. 1,6-8

Dental health education cara menyikat gigi yang benar dengan menggunakan metode alat bantu yang menarik untuk anak usia sekolah yang berupa pantum gigi, sehingga perhatian responden dapat dipusatkan kepala hal-hal yang di anggap penting oleh pendidik dan mencoba mempraktikkan secara langsung proses pendidikan yang telah diberikan sehingga dapat diamati secara teliti. Berdasarkan tabel 2. Menunjukkan bahwa dari 16 siswa kelas $\vee$ pada kelompok kontrol siswa mempunyai nilai pengetahuan kurang sebanyak 12 orang dan hanya 1 siswa yang mempunyai nilai pengetahuan baik. Berdasarkan tabel 2 . menunjukkan sebelum dilakukan penyuluhan kepada siswa kelompok perlakuan pada kelas $\checkmark$ dari 16 jumlah siswa yang menjadi sampel penelitian diperoleh hasil 9 siswa dengan nilai pengetahuan kurang dan sebanyak 2 siswa dengan nilai baik. Dan berdasarkan tabel 2 , menunjukkan setelah dilakukan penyuluhan kepada siswa kelompok perlakuan pada kelas $\checkmark$ dari 16 jumlah siswa yang menjadi sampel penelitian diperoleh hasil 8 siswa dengan nilai pengetahuan menyikat gigi baik dan sebanyak 1 orang jumlah siswa dengan nilai 
pengetahuan kurang. Hal ini menunjukkan bahwa dari pemberian penyuluhan pada siswa kelompok perlakuan dapat menambah pengetahuan siswa dalam menyikat gigi. $8-10$

Dental health education adalah suatu kegiatan pemberian edukasi kesehatan yang diberikan kepada siswa kelas V SDN Padangdangan 1. Penyuluhan ini memberikan sedikit modifikasi dalam penggunaan media untuk menyampaikan edukasi pada siswa, yaitu berupa pantum gigi. Selama penyuluhan siswa antusias, karena kemungkinan penyampain menarik dan mudah dipahami. Penyuluhan kesehatan yang disampaikan dengan efektif akan memberikan pengaruh yaitu pengaruh peningkatan pengetahuan, dan sesuai dengan hasil akhir yang diharapkan. 9.10

Pengetahuan kebersihan gigi siswa kelas $\checkmark$ SDN Padangdangan 1 sebelum mendapat DHE sebagian besar memiliki pengetahuan yang kurang. Setelah diberi penyuluhan kesehatan gigi dan dengan cara menyikat gigi disertai demontrasi menunjukan bahwa sebagian besar dari seluruh responden penelitian mempunyai tingkat pengetahuan menyikat gigi yang baik. Dental health education cara menyikat gigi disertai demonstrasi dapat meningkatkan pengetahuan kebersihan gigi pada siswa kelas $\checkmark$ SDN Padangdangan 1.

\section{DAFTAR PUSTAKA}

1. Wijayanti HN, Rahayu PP. Membiasakan Diri Menyikat Gigi Sebagai Tindakan Utama Dalam Upaya Peningkatan Kesehatan Gigi Dan Mulut Pada Anak. Jurnal Pemberdayaan Masyarakat Mandiri Indonesia (Indonesian Journal of Independent Community Empowerment). 2018 Aug 3;1 (1):7-12.

2. Mukhbitin F. Gambaran kejadian karies gigi pada siswa kelas $3 \mathrm{Ml} \mathrm{Al-}$ Mutmainnah. Jurnal Promkes. 2018 Dec;6(2):155-66.
3. Kiswaluyo K. Hubungan karies gigi dengan umur dan jenis kelamin siswa sekolah dasar di wilayah kerja puskesmas kaliwates dan puskesmas wuluhan kabupaten jember. STOMATOGNATICJurnal Kedokteran Gigi. 2015 Dec 15;7(1):26-30.

4. Nursalam. Konsep dan Penerapan Metodologi Penelitian IImu Keperawatan. Jakarta: Salemba Medika. 2013.

5. Nursalam. Model Asuhan Keperawatan Pada Pasien Yang Dirawat Di Rumah Sakit. Surabaya: Airlangga University Press. 2004.

6. Hidayat S, Mumpuningtias ED, Andriyani PS. Tingkat Pengetahuan tentang Kesehatan Gigi Berhubungan dengan Perilaku Perawatan Gigi pada Anak Usia 10-12 Tahun. STOMATOGNATIC-Jurnal Kedokteran Gigi. 2020 Oct 9;17(2):37-40.

7. Ramadhan A, Cholil C, Sukmana BI. Hubungan tingkat pengetahuan kesehatan gigi dan mulut terhadap angka karies gigi di smpn 1 marabahan. Dentino: Jurnal Kedokteran Gigi. 2016;1 (2):66-9.

8. Gayatri RW, Ariwinanti D. Tingkat pengetahuan kesehatan gigi anak sekolah dasar negeri kauman 2 malang. Preventia: The Indonesian Journal of Public Health. 2016 Dec 30; 1 (2):186-90.

9. Hestieyonini H, Kiswaluyo K, EY RW, Meilawaty Z. Perilaku menjaga kesehatan gigi dan mulut pada santri Pondok Pesantren Al-Azhar Jember. STOMATOGNATIC-Jurnal Kedokteran Gigi. 2015 Dec 15;10(1):17-20.

10. Yani RW, Hadnyanawati H, Kiswaluyo K, Meilawaty Z. Gambaran tingkat keparahan karies gigi anak sekolah dasar di 10 Kecamatan Kabupaten Jember. STOMATOGNATIC-Jurnal Kedokteran Gigi. 2016 Sep 1;12(2):42-5. 